
Granovitch

\title{
The longer the better: the effect of substrate on sessile biota in Arctic kelp forests
}

Concise title: Sessile biota in Arctic kelp forest

N.Shunatova, A.Granovitch

Department of Invertebrate Zoology, Biological faculty, Saint-Petersburg State University, Universitetskaya nab., 7/9, Saint-Petersburg 199034 Russia

D.Nikishina, M.Ivanov, T.Ivanova

Department of Ichtyology and hydrobiology, Biological faculty, Saint-Petersburg State University, VO 16th Line, 29, Saint-Petersburg 199178 Russia

J.Berge, P.E. Renaud

University Centre in Svalbard, Pb 156, N-9171 Longyearbyen, Norway

J.Berge

UiT The Arctic University of Norway, Faculty of Biosciences, Fisheries and Economics, N-9037 Troms $\varnothing$, Norway

P.E. Renaud

Akvaplan-niva, Fram Centre for Climate and the Environment, N-9296 Troms $\varnothing$, Norway

Corresponding author

e-mail: natalia.shunatova@gmail.com

phone: +7(921)9865839

\section{Abstract}

Kelps are ecosystem engineers and thus enhance biodiversity and subsidize food-webs in nearshore areas. Numerous studies describing diversity and abundance of biota associated with kelp have focused on sub-tropical and temperate waters while kelp forests at high latitudes, where kelp is predicted to expand in distribution, remain mostly unexplored. Kelp forests contribute significantly to regional biodiversity, and associated fauna and the kelp themselves play ecologically important roles as habitat and feeding areas. Here, we report patterns in diversity, abundance and seasonal dynamics of fouling organisms associated with different regions of Saccharina latissima and nearby substrates (including stones of the barren ground). The study was conducted in Kongsfjorden, a high Arctic fjord on the west coast of Spitsbergen; and samples were taken five times between September 2013 and January 2015. Trends in species richness of epifauna were similar for stones and holdfasts: higher in winter (due the presence of rare species), and lower in spring and autumn. Species richness and abundance demonstrated a clear tendency to increase in accordance with substrate stability. Stones housed the most diverse biota compared to living substrates. Holdfasts demonstrated similar patterns in species composition and abundance as stones due their close spatial arrangement and presence of demersal larvae in the most of fouling organisms. Similarly, assemblages on blades in prostrate kelp forests are influenced by the species inhabiting stones of the barren ground. Both biotic and abiotic factors, including habitat stability and proximity to source populations, contribute to these spatial and temporal patterns in faunal abundance and diversity. .

\section{Keywords}

Arctic kelp forest; sessile biota; seasonal dynamics; species richness; abundance; recruitment

\section{Introduction}

Kelp forests are widely distributed and highly productive marine coastal communities supporting diverse associated biota (Steneck et al. 2002). Being ecosystem engineers (Jones, et al. 1994), kelps serve as a food source, provide habitats for associated fauna and flora, and alter the hydrodynamic regime, sedimentation rates, and the ambient light climate below them. There is an extensive literature describing the influence of different environmental parameters on the flora and fauna associated with kelp forests, such as latitudinal gradients (e.g., Sheppard et al. 1977), seasonality (e.g., Christie et al. 2003), depth (Smith 1996; Smith et al. 1996), wave exposure (e.g., Schultze et al. 1990; Lippert et al. 2001; Spurkland and Iken 2011), and water flow (e.g., Duggins et al. 1990). These numerous studies have focused on kelp forests in subtropical and temperate waters, and only few have investigated kelp beds in the Arctic (Rozycki and Gruszczynski 1986; Lippert et al. 2001; Carlsen et al. 2007; Wlodarska-Kowalczuck et al. 2009). Most of published studies concern motile epifauna, while sessile organisms in such assemblage are often neglected (see Wlodarska-Kowalczuck et al. 2009 for a discussion of this). 
Kelp beds are complex three-dimensional structures including both living and non-living substrates of varying longevity: ephemeral (blades), short-lived (holdfasts, stipes, understory macroalgae and large sessile organisms such as some bryozoans and cirripedians), and stable (stones). It was shown for different species of Laminariales that the number of epifouling species is often lower on blades and stipes than on holdfasts (Norton 1971; Withers et al. 1975; Schultze et al. 1990; Christie et.al. 2003, 2009; Blight and Thompson 2008; WlodarskaKowalczuk et al. 2009), nevertheless kelp beds were never addressed as entire structure - though every part of which has a specific fouling assemblage but they affect each other.

Sugar kelps (Saccharina latissima) form prostrate kelp forests that cover the bottom with their blades (Steneck et al. 2002). The meristemic growth site is located above the stipe, thus the older part of the blade is shifted towards its distal end (Hornsey and Hide 1976; Seed and Harris 1980). S. latissima and some other species of Laminariales are known to live up to five years in the Arctic (Lüning 1990; Carlsen et al. 2007), and their holdfasts and stipes are perennial regions. Blades of Saccharina and Laminaria spp., on the other hand, are usually thought to be ephemeral substrate with the longevity of about a year, their growth starts in winter and reaches its peak during late spring and midsummer. The oldest portion of the blade is lost through abrasion and necrosis which is especially intense during autumn and winter (e.g., Lüning 1979, 1993; Seed and Harris 1980; Schaffelke and Lüning, 1994; Makarov and Shoshina 1996; Wiencke and Amsler 2012). Some authors, however, have reported that individuals of S. latissima and Laminaria digitata found in summer along the Greenland and Svalbard coasts had perennial blades (2-3 years), with prominent annual differentiation (Lund 1959; Borum et al. 2002; Carlsen et al. 2007). Based on these data, therefore, we expect kelp blades to be quite suitable substrate to study recruitment patterns, including seasonality of the fouling assemblage.

Seasonal changes in species richness and diversity of the assemblage associated with kelp have been demonstrated in many studies performed in temperate waters, but mostly for motile fauna.. To our knowledge, however, there is only a single mention about winter state of kelp forests in the high Arctic (Berge et al. 2015). and data on seasonal changes in sessile epifauna at high latitudes are lacking since winter sampling under Arctic condition is logistically difficult. The recent evidence for reproduction in Arctic fauna throughout the year (e.g. Kuklinski et al. 2013), and activity across the food web in the middle of the Arctic winter (Berge et al. 2015), suggest seasonal studies can be revealing as to life-cycles of kelp-associated fauna, and food resources for nearshore food-webs.

Based on the relative lack of data on epifauna on kelp blades, and their potentially important roles in nearshore ecosystem functioning, we assessed patterns of diversity, abundance and seasonal dynamics of fouling organisms associated with different regions of S. latissima and accompanying substrates (including stones of the barren ground) according to their longevity. Results will fill important knowledge gaps regarding winter kelp community structure in high Arctic, its seasonal changes and sessile fouling fauna in general. Moreover, such data create a basis for fruitful comparison for studies concerning settlement patterns of benthic invertebrates on artificial substrates. These data are needed to establish a baseline against which to evaluate inter-annual variability and climate change as kelp beds are predicted to expand in a warmer, ice-free Arctic (Krause-Jensen et al. 2012).

\section{Material and methods}

\section{Study area and sampling}

The material was collected in Kongsfjorden $\left(78^{\circ} 56^{\prime} \mathrm{N} 11^{0} 56^{\prime} \mathrm{E}\right.$, near Ny-Ålesund), a glacial fjord on the west coast of Spitsbergen. Kongsfjorden opens to the West Spitsbergen Shelf and is dominated by the influence of Atlantic waters (warm and saline), Arctic waters (cold and fresh), and glacial melt with pronounced seasonality (Cottier et al., 2005; Svendsen et al., 2002; Willis et al., 2006). During the last ten years, most of Kongsfjorden was free of fast-ice during winter (our observations, see also http://polarview.met.no).

Samples were taken by SCUBA diving in different seasons - first September 2013, then January, May and September of 2014, and finally January 2015. Sampling dates were chosen for several reasons: $(i)$ we expected to experience a range of blade maturity, from little new growth in January to maximum in May (see Wiencke et al. 2007 and references therein); and (ii) these seasons represent a range of food supply and meroplankton abundance and composition (Willis et al., 2006; Piwosz, 2009; Walkusz et al., 2009; Kuklinski et al., 2013; Stübner et al. 2016).

At each season, we took from 7 to 10 sets of samples from $2 \mathrm{~m}$ depth. Each set included a stone (hereafter SL-stone) with one or several individuals of S. latissima and understory macroalgae, and a sediment sample (hereafter, Gr-samples) taken by a cogged grab (sampling area $0.025 \mathrm{~m}^{2}$ ) near SL-stone. All stones found within sediment (grab) samples are referred hereafter as Gr-stones. In January and May, 2014 and in January, 2015 we also took six sets of samples at five meter depth. Stones with sessile organisms were selected from Gr-samples and weighed separately, the rest of Gr-samples were used for grain size analysis which was performed using the standard dry-sieve shaking method (Eleftheriou 2013).

When several individuals of $S$. latissima were attached to a single stone and it was impossible to separate their holdfasts we regarded the latter as a complex but single structure. 
The thallus of S. latissima possesses several microhabitats corresponding to its region (blade, stipe, holdfast). In several SL- and GR-samples understory macrolagae were present. Data from each substrate type were analysed separately since their characters differ and are likely very important for fouling organisms. Substrate types were divided into three categories according to their longevity: (i) ephemeral (about a year - blades of S. latissima); (ii) short-living (about 3-4 years - holdfasts and stipes of S. latissima, understory macroalgae and large bryozoan colonies); (iii) stable (stones). Only individuals of S. latissima that were older than 3 years were taken in the analysis; age was determined according to Kain (1963).

Almost all blades of $S$. latissima in January and all blades in May possessed a very prominent constriction which was lacking in September (Online Resource 1). This constriction divided a blade in two portions, proximal and distal, which differed in thickness, colour and abrasion and hence were referred, respectively, as " $0+$ " and " $1+$ " year-zones. Although both stipes and holdfasts continue to grow (though not so fast) during the whole life-span of a kelp individual, it is impossible to divide these parts of $S$. latissima thallus into year-zones.

For each substrate type (blade, stipe and holdfast of $S$. latissima, thalli of other macroalgae and stones) surface area was calculated. Blades (different year-zones separately), stipes, and holdfasts (preliminary split at bifurcations into pieces) were photographed with a size scale, and the diameter of stipes and holdfast pieces was measured. Area of blades and length of stipes and holdfast pieces were assessed using ImageJ 1.48v package. Thalli area of other macroalgae was estimated using the same procedure. Surface area of stones and barnacle shells was calculated using an inelastic net marked in a grid of $\mathrm{cm}^{2}$.

All sessile macrobenthic organisms were identified to the lowest possible taxonomic level, counted and weighed (wet-weight) with accuracy of $1 \mathrm{mg}$ (except bryozoans). We measured a square of bryozoan colonies (in $\mathrm{mm}^{2}$ ) and calculated their weight using species-specific coefficient (Denisenko, 1983). For solitary organisms density was estimated as the number of individuals per $\mathrm{m}^{2}$, for colonial organisms as the number of colonies per $\mathrm{m}^{2}$. Since densities during our survey were rather low there were no difficulties with counting number of hydrozoan or bryozoan colonies.

Whenever possible, we registered the presence of juvenile and adult stages: for bryozoans, ancestrula or small colonies including ancestrula plus up to four zooids were assigned as juveniles; for spirorbid polychaetes, recruits with tubes not yet coiled were ascribed as juveniles.

\section{Data analysis}

To estimate seasonal changes in the percentage of " $0+$ " year-zone we used General Linear Model analysis (GLM; continuous predictor - total area of blade, categorical factors - season, depth) and a post-hoc test (Fisher LSD). We only included data from Januaries and May because in Septembers blades were composed of " $0+$ " yearzone.

Species richness (hereafter, SR) was assessed with both three-way main effects analysis of variance (ANOVA; factors: substrate type, season, depth) based on all samples, and Spearmen correlation. For animals, we calculated the Shannon diversity index (H'; log base e) and D-index (effective number of species; see Jost 2006) based on density.

To compare assemblages on different substrates, we estimated density and biomass using the surface areas of corresponding substrates. To calculate total density and total biomass we used the sum of substrate surface area of all substrate types in the sample. The frequency of occurrence $(F)$ was calculated for each taxon as a percentage of samples where the taxon was found relative to the total number of samples. Rare species were defined as those occurring in only one (unique) sample. We identified dominant and subdominant species based on their frequency of occurrence $(\mathrm{F} \geq 75 \%)$ and density/or biomass $(\mathrm{N} \geq 15 \%$ or $\mathrm{B} \geq 15 \%)$ in at least one of the seasons.

Since macroalgal communities are usually quantified by biomass only, we used this parameter when we referred to the fouling assemblage as a whole. When assessing animals' distributions we used both their density and biomass values. Density of animals was chosen as a main abundance index when we traced seasonal changes.

ANOSIM (based on Bray-Curtis dissimilarity matrix) was used to test differences in fouling assemblages on different substrates and in different seasons. ANOSIM tests were based on $(i)$ biomass of all sessile organisms as well as (ii) density and (iii) biomass of animals only, and were made for two and five meter depth separately. Understory macroalgae from sediment samples from both depths as well as Gr-stones from five meter depth were excluded from this analysis due their low frequency of occurrence. SIMPER (based on Bray-Curtis dissimilarity matrix) analysis was also used to assess taxon contribution to sample heterogeneity at two meter depth.

We applied a three-way main effects ANOVA analysis (factors 'substrate type', 'season', 'depth') for assessing ( ) biomass distribution of animals and macroalgae; (ii) biomass of dominant and subdominant species. Understory macroalgae from sediment samples were excluded from these analyses due their low frequency of occurrence. Distribution of juvenile densities were tested with use of two-way ANOVA (factors substrate type and season) based on the data from $2 \mathrm{~m}$ depth since we have a full seasonal set of samples. ANOVA tests were based on fourth-root transformed data and were followed with post-hoc tests (Fisher LSD).

PCA analysis was based on fourth-root transformed data of average density of animals on each substrate type per season. PCA analysis was chosen because it allows to estimate the portion of variation for each factor and to trace loadings for each species. 


\section{Substrate characters}

\section{Results}

The main sediment fraction was categorized as pebbles and cobbles at two meters depth, and silted fine sand at five meters depth. At five meters depth we found several individuals of Saccharina latissima with holdfasts attached to very fine pebbles and almost entirely embedded within soft sediments. Such holdfasts were rather thinner and longer than those attached to cobbles and boulders (Online Resource 2).

Frequency of occurrence of understory macroalgae (see the list in the legend in Online Resource 3) was variable and quite low, and usually did not exceed $15-20 \%$ for each season, except for Chaetopteris plumosa-30\% and 50\% (January 2014 and 2015, respectively) and Polyides rotundus - 60\% and 40\% (September 2014 and January 2015, respectively). Average surface area of each algal substrate type varied both within and among seasons, but this value was several times larger for blades of S. latissima than for other substrates; average surface area of stones sampled was comparable to that of holdfasts and stipes (Table 1).

Usually in January and always in May, blades of $S$. latissima included both " $0+$ " and " $1+$ " year-zones while in September all blades lacked constriction and comprised only " $0+$ " year-zone (Online Resource 1). In both January samplings there were several individuals of $S$. latissima without " $0+$ " year-zone of blade and occurrence of such individuals was higher at five meters depth (5\% and 30\% in January 2014 at two and five meter depth, respectively, and $30 \%$ at $5 \mathrm{~m}$ depth in January 2015). The percentage of " $0+$ " year-zone varied according to the season $\left(\mathrm{GLM}, \mathrm{F}_{2,156}=112.7, \mathrm{p}<0.0001\right)$ but was independent from total blade surface area $\left(\mathrm{F}_{1,156}=0.21, \mathrm{p}=0.65\right)$ and thus the growth pattern of S. latissima was considered to be isometric (Fig. 1). Depth did not affect the percentage of " $0+$ " year-zone $\left(\mathrm{F}_{1,156}=3.42, \mathrm{p}=0.07\right)$ but analysis revealed a significant interaction (season*depth; $\mathrm{F}_{2,156}=5.53, \mathrm{p}=0.005$ ). In Januarys at $5 \mathrm{~m}$ depth, the percentage of " $0+$ " year-zone was lower than at $2 \mathrm{~m}$ (post-hoc test; $\mathrm{p}<0.001$ ) but this index was similar at both depths in May (post-hoc test, $\mathrm{p}=0.18$ ). Post-hoc tests also demonstrated that the percentage of " $0+$ " year-zone was similar in January 2014 and 2015 ( $\mathrm{p}=0.81$ and $\mathrm{p}=0.48$ for two and five meter depth respectively).

Rarely, some substrates (more often, "0+" year-zone and stipe of S. latissima) were not colonized by sessile organisms (i.e., they were empty) and their portion varied during the survey. All understory macroalgae were empty in May, 2014.

\section{Species richness and species composition}

In total, 111 taxa of sessile biota were recorded including 80 taxa (57 to species level) of animals and 31 taxa (23 to species level) of macroalgae; Online Resource 3 gives the full list of taxa. Such a huge gap between the number of identified species and the number of registered taxa was due to numerous juveniles in the samples, especially bryozoans, which often possess identification characters only at adult stage.

Species richness (hereafter, SR) on every substrate type was highly variable and ranged from 0 to 39 species per sample. Among animals, Bryozoa was the most species-rich group (56 taxa and 43 species) and among epiflora, brown algae (Orchophyta: Phaeophyceae - 16 taxa and 11 species) and red algae (Rhodophyta: Floridiophyceae 11 taxa and 10 species) demonstrated the highest diversity. Mean and total values of SR of macrobenthos were the lowest on blades and stipes and the highest on SL-stones (Fig. 2, Table 1, see also Online Resources 4 and 5). SR pattern was similar both for animals and macroalgae and at the both depths (Spearmen correlation, $\mathrm{p}<0.05$ for all paired combinations).

A three-way main effects ANOVA demonstrated that SR of animals was significantly influenced by all three factors: 'substrate type' $\left(\mathrm{F}_{6,41}=15.01, \mathrm{p}<0.0001\right)$, 'depth' $\left(\mathrm{F}_{1,41}=10.96, \mathrm{p}=0.002\right)$, and 'season' $\left(\mathrm{F}_{4,41}=2.9, \mathrm{p}=0.038\right)$. Substrate type had the highest effect size $(63.2 \%)$ while effect sizes of season and depth were rather low $(8.2 \%$ and $7.7 \%$, respectively). SR of epiflora demonstrated similar patterns, but only substrate type had a significant effect (three-way main effect ANOVA, $\mathrm{F}_{6,41}=17.32$, $\mathrm{p}<0.0001$; effect size $=68.5 \%$ ). Post-hoc tests (Fisher LSD, $\mathrm{p}<0.05$ ) confirmed that SR of sessile macrozoobenthos on SL-stones and SR of macroalgae both on SL- and Gr-stones differed significantly from other substrates.

Seasonal changes in total SR of animals at two meters depth were similar on SL-stones and holdfasts (Spearman correlation, 0.98, $\mathrm{p}=0.0004$ ) with the highest values of total SR detected in winter samples both in 2014 and 2015 (Fig. 3; Table 1). Contrary to this, we failed to trace any trend in seasonal fluctuations in SR of animals on blades and stipes (Fig. 3) and total SR were considerably lower on these substrates (Table 1). Total SR of macroalgae was the lowest in September, 2013 and January, 2014 but increased to the highest values in the same seasons a year later (Fig. 3). SR of macroalgae varied on different substrate types with the lowest values registered for stipes (a single species Styctiosyphon tortilis was found only once - in May, 2014).

Species composition was highly variable on each substrate type. Almost half (46\%) of registered taxa demonstrated substrate preferences (Online Resource 3). Two species (Buskia nitens and Cerceis spirillum) were found only on understory macroalgae while about $66 \%$ of taxa never resided on them (the majority of such species were recorded on stones). Nine species were found only on Saccharina latissima (seven only on holdfasts, two both 
on holdfasts and stipes) while 36 taxa were resided solely on stones, of which two species inhabited only Gr-stones, 21 taxa occurred only on SL-stones, and 13 taxa were found both on SL- and Gr-stones. There were no taxa specific for blades or/and stipes. We registered 13 taxa residing on all regions of the S. latissima thalli and both SL- and Grstones; the rest of the 56 taxa inhabited several substrate types in different combinations.

For animals, both Shannon diversity index (H') and D-index (effective number of species) had the highest values for stones and the lowest for blades and stipes (Table 1), and demonstrated seasonal fluctuations both at two and five meters depth. A three-way main effects ANOVA revealed that D-index was significantly influenced by substrate type $\left(\mathrm{F}_{6,44}=16.94\right.$, $\mathrm{p}<0.0001$; effect size $\left.=72.3 \%\right)$ but was independent of season $\left(\mathrm{F}_{6,44}=0.56, \mathrm{p}=0.69\right)$ and depth $\left(\mathrm{F}_{6,44}=0.63, \mathrm{p}=0.43\right)$. Values of $\mathrm{D}$-index for blades and stipes significantly differed from other substrates (posthoc test; Fisher LSD, $\mathrm{p}<0.05$ ).

Within a sample, we found up to six species of understory macroalgae with different thallus morphologies and surface area. SR tended to be higher when more understory algae were recorded, but the frequency of occurrence of understory algae was too low to address this trend statistically.

\section{Occurrence and abundance of fouling organisms}

Total biomass of sessile organisms on blades and stipes was considerably lower than that on stones and holdfasts (Fig. 4). During our survey we also found noticeable seasonal fluctuations in total biomass, which was rather high in January, 2014 and September, 2014 and lower in other seasons. It is not surprising that biomass of macroalgae on both blades and stipes was close to zero and was rather low on holdfasts (except for September, 2013 and January, 2014) compared to stones. Biomass on all parts of Saccharina latissima was dominated by animals. A similar pattern was revealed for SL-stones in September, 2013 and January, 2014 while in the rest of the seasons the biomass ratio of animals and algae was opposite. Gr-stones were dominated by macroalgae in May, 2014 and January, 2015 but in September, 2014 biomass ratio of macrolagae and animals was almost equal. Total biomass of sessile zoobenthos was the lowest in May, 2014 and the highest in January, 2014.

ANOSIM tests based on biomass of all sessile organisms, as well as on density and biomass of animals, indicated that assemblages were significantly different on all substrate types at both depths (statistic $\mathrm{R}$ values varied from 0.5 up to 0.61 ). Within each substrate type at $2 \mathrm{~m}$ depth, seasonal fluctuations were not so prominent (statistic $\mathrm{R}$ values varied from 0.19 up to 0.3 ), while at $5 \mathrm{~m}$ depth the degree of dissimilarity among seasons was higher (statistic $\mathrm{R}$ values varied from 0.42 up to 0.62 ).

We found the highest dissimilarities in biomass distribution among substrates at $2 \mathrm{~m}$ (Table 2), while seasonal differences were somewhat lower (except for holdfasts). Sample heterogeneity was also high and comparable with seasonal dissimilarities (Table 2).

A three-way main effects ANOVA demonstrated that biomass both of animals and macroalgae was influenced by substrate type $\left(\mathrm{F}_{5,294}=24.7\right.$, $\mathrm{p}<0.0001$; effect size $=27.2 \%$ for animals and $\mathrm{F}_{5,294}=35.07, \mathrm{p}<0.0001$; effect size $=35.7 \%$ for algae $)$ and season $\left(F_{5,294}=6.9, p<0.0001\right.$; effect size $=6.1 \%$ for animals and $F_{5,294}=3.19$, $\mathrm{p}<0.014$; effect size $=2.6 \%$ for algae). Biomass distribution was independent of depth.

Both density and biomass of sessile zoobenthos demonstrated high correlations with substrate type. Thus, the first component (21.4\%) in the PCA analysis (based on average density of animals on each substrate type per season) corresponded to substrate type since blades and stipes had the lowest scores (from -3.79 up to -2.69) and SL-stones had the highest one (from 1.6 up to 8.9) while the rest of substrate types occupied intermediate positions (Fig. 5). This correspondence was also confirmed by the lowest loadings for the species that were often registered at the blades and stipes (-0.35 and - 0.14 for Celeporella hyalina and Circeis armoricana, respectively), as well as by the highest loadings for species found mostly on stones ( 0.89 for Tegella arctica; see also the right frame on Fig. 5). Thus along the first component (from left to right) there was an "age-gradient" of substrates: from ephemeral (blades) through short-living (stipes and holdfasts), towards stable (Gr- and SL-stones). The second principle component $(13.8 \%)$ corresponded to the differences between living and non-living substrates located directly on the bottom: holdfasts and understory macroalgae had the highest scores (always positive) while scores of Gr-stones (always) and SL-stones (usually) were negative. The lowest loadings were found for species more frequently inhabiting stones, while the highest loadings were registered for species usually occupying understory macroalgae and holdfasts (see the list in the left box on Fig. 5). Together, the first and second components explained about one third of dispersion, the rest of the components corresponded to the seasonal variation of density of fouling animals on stones.

We found high temporal heterogeneity in the structure of fouling community. Among macroalgae, dominant species differed within each season on different substrates and changed on each substrate during the survey (Fig. 6, Table 1, see also Online Resource 4) so we failed to trace any consistent pattern. Among animals, blades and stipes were dominated in biomass by a single species (Circeis armoricana and Celeporella hyalina, respectively) during the survey. Contrary to this, dominant species on other substrates varied in different seasons (Fig. 6, Table 1, and Online Resources 4 and 5). And since a dominant species in one of the seasons was usually registered as a subdominant in others, we refer to this collection of taxa as 'leading species'. All dominant and leading species were found on at least three substrate types, among which stones and holdfasts were always represented (except for Alcyonidium gelatinosum that was not registered on holdfasts). In addition to this group, we distinguished several species (Porella smitti, Tricellaria ternate, Crisia eburnea, Alcyonidium mamillatum, Porella minuta, Buschiella 
quadriangularis) with high frequencies of occurrence ( $\mathrm{F} \geq 70 \%)$, but with rather low density and biomass. Several species were rather rare on a given substrate type (Online Resource 3).

A three way main-effects ANOVA demonstrated that substrate type and season significantly influenced abundance indices of dominant and leading species (Table 3), but effect size of substrate type was higher. Only three species were significantly influenced by depth and, moreover, effect size of this factor was extremely low (about $2 \%$ of explained variation).

\section{Distribution of juveniles}

We found juvenile stages of bryozoans, barnacles and spirorbid polychaetes; and among them, eight taxa were identified to species level and seven to genus level (Online Resource 3).

Juveniles usually demonstrated the same substrate preferences as adults, but in several cases they were also registered on substrates where adults were absent (e.g., juveniles of Dendrobeania sp. were found on stipes, Tubulipora sp. on stones, and Balanus balanus on blades). Juveniles of some taxa were recorded in specific season(s), e.g., only in September (Alcyonidium sp.), both in September and in January (Circeis armoricana, Tubulipora sp., B. balanus, and Porella minuta), both in January and May (Tricellaria sp.). Contrary to this, juvenile stages of some taxa (e.g., Callopora craticula, Cribrilina annulata, Celeporella hyalina, Crisiella producta, Bushiella sp., Dendrobeania sp.) were present in all seasons during the survey, and on at least one type of perennial substrates. A two-way ANOVA (factors 'substrate type' and 'season'; $\mathrm{df}_{1}=3, \mathrm{df}_{2}=2$ ) demonstrated that the distribution of juveniles of some taxa (Bushiella sp., Dendrobeania sp., C. hyalina, C. armoricana, C. annulata, C. producta) was significantly influenced by both factors ( $\mathrm{p}<0.001$ in all cases except for $C$. hyalina, season, $\mathrm{p}=0.024)$. Two taxa (Alcyonidium sp. and Tricellaria sp.) were significantly affected only by season ( $<0.005$ in both cases), and some taxa (Paradexiospira sp., B. balanus, C. craticula, Patinella sp.) were only influenced by substrate type ( $\mathrm{p}<0.005$ in all cases). Distribution of juveniles of several species (C. hyalina, C. armoricana, C. annulata, C. producta and Bushiella sp.) were also influenced by interactions of factors (substrate*season), and highest densities of juveniles were recorded for different substrates in various seasons.

On blades, we recorded juveniles of six taxa (C. armoricana, C. hyalina, C. producta, Patinella sp., C. annulata, Tubulipora sp.) but not in May, when they were registered on perennial substrates. During the survey, their densities were about half that of adults (Fig. 7). In Januarys, juveniles of all species were found within the ' $1+$ ' year-zone of blades.

\section{Methodological issues}

\section{Discussion}

Traditionally, abundance of sessile biota is estimated using percent cover as a main index. The principal advantage of this method consists in possibility to describe both community structure and abundance without timeconsuming procedure of calculating density and biomass, particularly since colonial animals present challenges here. Doubtless, spatial competition on stable substrates may be very high and sometimes it can be difficult to count the number of colonies of hydrozoans or bryozoans. However, percent cover data are only comparable when substrates are more or less equal in size, which is not always the case. Therefore, different methods for assessing species number and/or abundance of epibionts were used in previous studies, such as number of epifaunal organisms per plant (Norton 1971), area of substrate surface (e.g., Rozycki and Gruszczynski 1986), weigh of basibiont (e.g., Kain 1971; Lippert et al. 2001), volume of basibiont (e.g., Edwards et al. 1980; Smith et al, 1996; Christie et al. 2003, 2009; Blight and Thompson 2008) or length of stipe (e.g., Christie et al. 2003). Such a diversity of methods hinders the comparability of different studies of species abundance. Most of these methods are applicable to the study of abundance of mobile epifauna, but one of the most important factors for studying the distribution of sessile organisms is the area of substrate surface,. This method is also of particular importance when comparing diversity and abundance across different substrates.

\section{Phenology of blade extension}

We documented growth of Saccharina latissima in Kongsfjorden in early January (though not all individuals had started to grow by mid-January).The blade at this time includes a small ' $0+$ ' year-zone and a large ' $1+$ ' yearzone. Growth slows down in autumn and the distal part of the blade is destroyed due to physical forces, so by the end of September the blade is composed only of ' $0+$ ' year-zone.

Our results are in agreement with previously reported data from European coast (e.g., Lüning 1993; Schaffelke and Lüning 1994; Makarov and Shoshina 1996). Carlsen et al. (2007), however, reported 3-year-old blades both of S. latissima and Laminaria digitata from the same locality (Kongsfjorden, west Spitsbergen), and blades of 2-3 years were also reported from Greenland coast (Lund 1959; Borum et al. 2002). Such a difference is quite surprising and difficult to explain. Perhaps such individuals were rather rare and were collected in sheltered localities and/or deeper where blade abrasion is rather slow. In addition they probably were a specific target in these studies while we sampled randomly and did not find such old blades. However, since in all these cases material was collected in high Arctic glacial fjords with mid-summer decreases in light and nutrient loads due to glacial runoff, one can speculate that such abrupt changes in abiotic drivers might cause non-cyclic slowing down or even stoppage of blade growth, resulting in constriction formation. Although such a phenomenon was never reported for 
Laminariales species, interaction of environmental factors (such as irradiance, temperature, nutrients, etc.) can affect algal growth in ways that are not fully understood (reviewed in Wiencke et al. 2007, 2009; Gomez et al. 2009; Wiencke and Amsler 2012).

\section{Assessment of species richness}

Epifauna associated with all Laminariales species often demonstrate large similarities across studies, especially regarding SR and species composition (Schultze et al. 1990; Lippert et al. 2001; Carlsen et al. 2007; Wlodarska-Kowalczuk et al. 2009). Based on this, we expected to find similar levels of species diversity in our survey and earlier studies, especially those conducted in the same region and locality (Kongsfjorden, west coast of Spitsbergen). Data from two previous studies (Lippert et al. 2001, Carlsen et al. 2007) allow a detailed comparison with our results for sessile epifauna. Strikingly, the number of zoobenthic taxa recorded on S. latissima in our survey was at least two times higher than in either of the other studies. Nevertheless, the higher level taxonomic compositions found the present study and reported by Lippert et al. (2001) are consistent, and the most abundant taxonomic groups are similar, e.g. we registered $80 \%$ of the bryozoan species listed by Lippert and coauthors. On the other hand, species composition reported by Carlsen et al. (2007) differs significantly: sponges, barnacles and hydrozoans were not mentioned in their study, only about $50 \%$ of bryozoan species coincided, and spirorbid polychaetes were represented by other species. Data reported by Rozycki and Gruszczynski (1986) for four species of overstory kelp collected on the west coast of Spitsbergen revealed a similar pattern: SR in our survey is three times as high while taxonomic composition is comparable. Such differences in both cases are most likely due the combination of two factors: small numbers of samples in these studies ( 8,20 and 56, respectively) and spatial heterogeneity. Even at small scales (one to few meters) it is typical for the distribution of biota and assemblage composition to vary considerably (e.g., Arroyo et al. 2004; Anderson et al. 2005; Kuklinski et al. 2006; Yakovis et al. 2008; Miguel et al. 2010).

In our survey we found 111 taxa in 68 samples including 110 individuals of $S$. latissima which is quite far from assessing true species richness. Even in an extensive study of motile and sessile epifauna associated with macroalgae, and based on rather numerous samples (in total, 403 samples including 356 individuals of three species of overstory kelp), the observed number of motile and sessile taxa was 208, a value much lower than Chao2 estimated value (Wlodarska-Kowalczuk et al. 2009). This research was also performed in Svalbard waters (Hornsund), and demonstrated diverse sessile fauna among which Bryozoa and Hydrozoa were the most species rich groups, with 70 and 37 species, respectively (compared to 56 and 8 species in the present study). Unfortunately, Wlodarska-Kowalczuk and coauthors did not provide any details of epifauna distribution on a given species of macroalgae (or at least mention them to be located either on overstory or understory kelp) and this prevents us from further comparison. Besides differences in number of samples, such a huge gap in the species richness probably resulted from different sampling depth and larger number of sites sampled.

Habitat complexity and structural heterogeneity are well known to beget diversity and increase richness and abundance in different habitats (e.g., Dean and Connell, 1987; McCoy and Bell 1991; Gee and Warwick 1994; Knowles and Bell 1998; Kelaher and Castilla 2005; Matias et al. 2010; Kovalenko et al. 2012; St.Pierre and Kovalenko 2014; Loke and Todd 2016). Abundance, biomass, and diversity of motile epifauna are directly related to algal species composition (e.g. Attrill et al. 1996; Parker et al. 2001; Christie et al. 2003; Norderhaug et al. 2007). As shown by Leclerc et al. (2015), the abundance of mobile fauna in kelp epiphytes may interfere with habitat complexity on the understory and kelp size-density structure (density of adults hosting abundant epiphytes). Armitage and Sjøtun (2016) demonstrated that shared macroalgal epiphytes lead to higher similarity between the zoobenthic communities associated with Codium fragile and Fucus serratus. Unfortunately, such data lack for sessile epifauna, anyway, one can speculate that (i) substrate surface area available for recruits increases with the habitat complexity; (ii) understory macroalgae alter hydrodynamic regime within the bottom water layer making it more turbulent which is supposed to facilitate in the food uptake by suspension feeders (e.g., Shimeta and Jumars 1991; Vogel 1994).

Thus, the higher values of SR and somewhat different species lists reported by Wlodarska-Kowalczuk and coauthors (2009) may be due to higher habitat complexity and structural heterogeneity owing to the presence of more numerous understory macroalgae with diverse thallus structure in their samples. Understory macroalgae in our survey were dominated by filamentous and branching forms (see species list in Online Resource 3), and their morphology and limited surface area impede settlement by sessile biota. Although the occurrence of understory macroalgae in our samples was rather low, we noted that SR tended to be higher when more understory algae were recorded. This observation, and the quite different species lists of understory algae in the present study and that reported by Wlodarska-Kowalczuk et al. (2009), we suggest that SR and diversity of sessile biota associated with overstory kelp is also highly influenced by species composition and abundance of understory macroalgae.

\section{Effect of substrate type}

It has been shown that the number of fouling species on different species of Laminariales is often lower on blades and stipes than on holdfasts (Norton 1971; Withers et al. 1975; Schultze et al. 1990; Christie et.al. 2003, 2009; Blight and Thompson 2008; Wlodarska-Kowalczuk et al. 2009); and our data confirm this observation (see Fig. 2). In the present study, SR, density and biomass of epibionts on blades and stipes were two orders of magnitude lower than on other substrate types (see Fig. 2, 3,4). According to our results, substrate type, reflecting 
longevity, surface characteristics, and likelihood of disturbance, among other factors, more strongly influenced distribution of fouling biota than seasonality or depth. This hierarchy of factors was found for SR, diversity, and abundance indices of the whole assemblage, as well as for dominant and leading species (see Table 3, Fig. 6).

Numerous studies have demonstrated the effect of substrate type on SR, diversity, species composition of epifauna (e.g., Seed and O'Konnor 1981; Lippert et al. 2001; Kuklinski and Barnes 2005; Villegas et al. 2008). Our data are in agreement with them. In the present study, SL-stones housed the most diverse biota compared to living substrates (97 and 61 taxa, respectively, out of 111 - see Online Resource 3), which is probably due to higher substrate stability and, perhaps, surface quality, in particular, rugosity. Numerous fouling settlers prefer small cavities, and rough and convex surfaces (e.g., Seed and O'Connor 1981; Ward and Thorpe 1989; Kuklinski and Barnes 2005). Gr-stones demonstrated a lower ratio of substrate-confined species and lower values of total SR compared with SL-stones, making GR-stones more similar to ephemeral substrates. Although species composition, density, and biomass of fouling biota on Gr-stones were similar to those on SL-stones, their values were highly variable during the survey so that Gr-stone samples formed an elongated cluster along first component axis in PCA analysis (see Fig. 5) which corresponded with an "age-gradient" of substrate type. Such features are very likely to be explained by somewhat smaller size of some Gr-stones (see Table 1) and their lower weight resulting in more frequent overturning caused by strong wave action, and, in addition, smaller surface area available for recruits. We have indirect confirmation of disturbance (overturning) frequencies of small Gr-stones during our survey as the presence of dead bryozoan colonies with destroyed frontal walls of zooids which were more numerous in samples collected in September, 2014 and January, 2015, sampling periods that were preceded by strong storms. These results confirm the data of numerous previous studies reported that the stone size is of prime importance for colonization patterns (e.g., Osman 1977; Sousa 1979; Wilson 1987; Kuklinski et al. 2006; Grzelak and Kuklinski 2010). As suggested before, assemblages on small stones are likely in a state of constant transformation and are composed of opportunistic species with very short life cycles (Kuklinski et al. 2006; Kuklinski 2009).

Bryozoans in Svalbard waters show no indication of being substrate-specific (Kuklinski and Barnes 2005). Contrary to this, some bryozoan species in this study were only found on a single substrate type (Online Resource 3). Realizing that we had a smaller number of samples, a limited depth range of sampling, and a single sampling site, we do not suggest such species are substrate-specific, but instead designate them as 'substrate-confined'. The proportion of such substrate-confined species was higher for stones compared to Saccharina latissima and, they resided on perennial regions of kelp thallus and not on blades. Absence of substrate-confined species on blades probably resulted from the ephemeral and unstable nature of the substrate, which prevents the majority of sessile animals from finishing their life-cycles.

Although the percentage of empty substrate was rather low during the survey (see Table 1), we never registered examples of spatial competition (overgrowth), even on stones. This suggests that epifaunal communities on all substrates were in early stages of colonization.

Among animals, we can distinguish two groups of dominant and leading species: the first was specific for blades+stipes and the second for stones, while the list of leading species on holdfasts was a mixture of both groups (see Table 1, Online Resources 4 and 5). Since the same trend was also found for species composition, we suggest that assemblage of epibionts on holdfasts is highly influenced by that on stones.

Some dominant species are consistent with those previously mentioned for Svalbard waters. Thus, Celeporella hyalina was reported to dominate macroalgae (Lippert et al. 2001; Kuklinski and Barnes 2005) and in the present study this species dominated on stipes of S. latissima and was a subdominant on blades and holdfasts, and on understory kelp. The bryozoan assemblages on shallow subtidal stones in Arctic waters were dominated by Harmeria scutulata (e.g., Barnes and Kuklinski 2003; Kuklinski and Barnes 2005; Kuklinski et al. 2006; Kuklinski 2009). During our survey, $H$. scutulata was dominant or subdominant species on SL-stones, and only once took a subdominant position on Gr-stones. The other leading species on stones (Cribrilina annulata, Tegella arctica, Electra arctica) have also been shown to be abundant in some studies, but contrary to our data, their density was reported to be at least an order of magnitude lower compared to that of $H$. scutulata (e.g., Barnes and Kuklinski 2003; Kuklinski and Barnes 2005; Kuklinski et al. 2006; Kuklinski 2009).

In the present study, SR and abundance demonstrated a clear tendency to increase in accordance with substrate longevity, from ephemeral (blades) through short-lived (holdfasts and understory macroalgae) towards stable (stones) substrate. Short-lived substrates are quite specific: they are perennial and grow during their life-span, increasing their surface area which provides empty space for recruits. On the other hand, different parts of the S. latissima thallus vary in rigidity; morphology (shape); and, as a consequence, local water flow velocity and regime; and also exometabolite composition (some of them may attract recruits and some may prevent them from settlement). All these points may affect the attractiveness of different parts of kelp thallus and result in higher diversity and abundance of biota associated with the holdfast.

\section{Seasonal dynamics and recruitment}

During the survey, we found the highest values of SR of sessile zoobenthos in both Januaries but we registered very low values of epifloral SR in January, 2014 and the highest in January, 2015. Unfortunately there are scarce data on seasonal changes of sessile biota associated with kelp and mainly they concern temperate waters. Contrary to our findings, Withers et al. (1975) mentioned richer epifauna in summer comparing to winter, and Christie et al. (2003) specified that SR was not affected by seasonal changes but abundance of epifauna was 
significantly related to season. Carlsen et al. (2007) reported that total SR of epifauna on blades of Saccharina latissima and Laminaria digitata was significantly higher in May than in late August (considering only sessile species from their list, 15 and 6 taxa, respectively). We sampled in May and late September and found an opposite pattern (Fig. 3). There are several possible explanations for these dissimilarities: (i) interannual variability; (ii) spatial heterogeneity; (iii) the difference of one month between autumn sampling dates (we sampled a month later) resulting in colonization of blades by newly settled recruits which probably had not yet appeared in August.

SR of epifauna in the present study demonstrated seasonal trends that were similar for SL-and Gr-stones and holdfasts: it was higher in both Januarys and lower in May and both Septembers with comparable values of the same seasons in subsequent years (see Fig. 3). Collation of species lists for these substrates reveals that the highest values of SR in Januarys were due the presence of rare species (Online Resource 3), which most likely results from their settlement between September and January. The decrease of SR in May and September may be caused by the effect of abiotic factors (e.g., abrupt drop of salinity and increase of sedimentation rate in summer are quite typical in glacial bays, and runoff from the Red River in autumn flows directly over the kelp bed we studied), juvenile mortality and/or predation impact.

Seasonal fluctuations in total biomass of fouling assemblages were connected with different relative importance of macroalgae and zoobenthic organisms' abundance in different seasons. The fouling community in May and September, 2014 was dominated in biomass by understory macroalgae due their intensive growth during spring and summer. Low values of macroalgal biomass recorded in September, 2013 are probably explained by interannual variability and spatial heterogeneity of a small scale. The same factors seem to be more probable to affect also the biomass ratio of macroalgae and animals in corresponding seasons (Septembers and Januaries). Low frequency of occurrence of all species of understory macroalgae in the samples and short period of our observations prevent us from any further speculation.

Seasonal variability in the abundance of juvenile forms on holdfasts and stones registered in the present study (see Fig. 6) likely reflects spatial patterns in adult populations, seasonal recruitment, and/or differential juvenile mortality. Unfortunately, data on life cycles or life history of many benthic species from the Arctic are limited, but life-history strategies of dominant taxa in this study varied considerably. Settlement peaks of some taxa in midwinter, and lack of distinct seasonality in other taxa, highlight the little-recognized complexity of larval strategies for Arctic benthos, where larval appearance is often presumed to be associated with the spring phytoplankton bloom.

We found distinct seasonality in occurrence of some juvenile stages that likely reflects seasonality in the reproduction of such species. Similarly, those species with juveniles found in both in September and January likely have either a long recruitment period with very slow growth, or stoppage of growth when food supply is low. The presence of juveniles of some taxa in all seasons at least on one type of perennial substrates indicates year-round reproduction in such species, which was also confirmed by presence of larvae in the ovicells of some bryozoans (e.g., Callopora craticula, Cribrilina annulata, Celeporella hyalina) during every sampling period. These species are known to be opportunists with fast growth. Absence of juveniles of these species on blades in May (see Fig. 7) despite their presence on perennial substrates at the same time let us suggest a year-round reproduction of these species and, at the same time it is very likely that their larvae avoid blades during spring presumably due a specific exometabolites composition and biofilm on them. Many authors pointed the differences of epifaunal assemblages associated with different species of macroalgae (e.g., Seed and O'Connor, 1981; Blight, Thompson, 2008; Parker et al., 2001; Christie et al., 2009; Grzelak and Kuklinski, 2010). For example, even for kelp species with similar thallus structure difference in SR of epibionts was reported; this was explained by higher production of antifouling chemicals by Laminaria ochroleuca compared to L. digitata (Bligth, Thompson, 2008). Later, Hellio et al. (2000, 2002 ) found that exudates of $L$. ochroleuca had higher levels of antimicrobial activity comparing to L. digitata, particularly against microalgae and marine fungi which together with bacteria are significant contributors to biofilm formation and thus affect the subsequent attachment of other epibiont organisms.

Only a few of the animals recorded in our study (bryozoan Electra arctica, cirripedian Balanus balanus) have planktotrophic larvae which spend quite long periods in the water column (pelagic larvae), while the rest of sessile epifauna - spirorbid polychaetes, ascidians, sponges, hydrozoans and the rest of bryozoans - have lecithotrophic larvae. Spirorbid larvae are regarded as pelagic in spite of their very short swimming period (e.g., from 15 minutes up to few hours reported for Spirorbis spirorbis - Knight-Jones 1951, 1953; see also an extensive review in Kupriyanova et al. 2001). However, it was shown that presence of a favourable substrate reduced the duration of pelagic phase, for example, up to $91 \%$ of released larvae of Spirorbis rupestris metamorphosed even without becoming pelagic (Gee 1963). Swimming period of both sponge and solitary ascidian larvae varies in different species within 2-24 hours (e.g., Berrill 1930; Svane and Young 1989; Ereskovsky, 2010), and although they are assumed to be pelagic, they have not been registered in meroplankton samples in Kongsfjorden (e.g., Piwosz, 2009; Walkusz et al. 2009; Kuklinski et al. 2013; Grenvald et al. 2016; Stübner et al. 2016). In the few studies concerning behaviour of hydrozoan planulae, it was demonstrated that they have short swimming or crawling period (usually 10-12 hours but up to 2-3 days - Williams 1965; Sommer 1992; Orlov 1996, 1997; Migotto 1998) and only very rarely can they be transported by ambient currents (see Migotto 1998). Bryozoan lecithotrophic larvae also have a short swimming period which they spend within the bottom water layer (for different bryozoan species, from several hours up to 3-4 days - Shunatova, unpublished data; see also Ryland 1974, 1976; Reed 1991). Pearse (1969) and Mileikovsky (1971) termed such larval type as demersal and both of them suggested that it may be more common for benthic invertebrates than previously thought (see also Gerrodette 1981). 

Based on these data, it is likely that the distance traveled by demersal larvae does not exceed a few meters (and usually is less than one), so that they are more or less restricted to the area where maternal colony (or individual) is located. This perspective can help to explain ( $i$ ) the higher similarity of SR, species composition, and abundance of sessile epifauna associated with SL-stones and holdfasts, and (ii) the lower SR and abundance on blades and stipes. This is consistent with observations of Christie et al. (2003) who found that epifauna on the stipe of Laminaria hyperborea was richer in regions closer to the holdfast. Meyer et al. (2017), also noted very high spatial heterogeneity of settlement on panels deployed for different periods in a 12-month period in several Svalbard fjords, which they interpreted to reflect short larval periods and, thus, close relationships between settlers and nearby adult residents. Thus, larval characteristics are likely of the primary importance for colonization patterns of fouling assemblages. The presence of demersal larvae in most registered species and close spatial arrangement of holdfasts and SL-stones, as well as blades and stones of the barren ground, result in similar patterns in species composition and abundance for each pair of substrates.

\section{Conclusions}

This study demonstrated that SR, diversity, and abundance were higher on holdfasts than on blades or stipes of kelp in a Svalbard fjord. Substrate type, reflecting longevity, surface characteristics, and likelihood of disturbance, among other factors, more strongly influenced distribution of fouling biota than seasonality or depth. This hierarchy of factors was found for SR, diversity, and abundance indices of the whole assemblage, as well as for dominant and leading species. Among numerous differences between discussed, substrate types their longevity had quite prominent effects on species composition. Additionally, presence of demersal larvae in most fouling species and close spatial arrangement of holdfasts and SL-stones as well as blades and stones of the barren ground result in similar patterns in species composition and abundance for each pair of mentioned substrates. Based on the data reported for motile epifauna and our qualitative observations, we suggest that SR and diversity of sessile biota associated with overstory kelp is also highly influenced by species composition and abundance of understory macroalgae. But this point deserves to be a subject of a separate study.

\section{Acknowledgements}

We would like to thank the staff of Kings Bay AS (Ny-Ålesund, Svalbard) for hospitality. Special thanks to Daniel Vogedes, Peter Leopold, Rupert Krapp and Carl Ballantine for their assistance in sampling. We are grateful to Marina Varfolomeeva ( $\mathrm{SPbSU}$ ) for her support with data analysis. This study was funded by Norwegian Research Council grant Marine Night (project number NRC 226417) and partly by Saint-Petersburg State University project 1.42.1277.2014.

The authors declare that they have no conflict of interest.

\section{Conflict of interest}

Ethical approval

All applicable international, national, and/or institutional guidelines for the care and use of animals were followed.

\section{References}

Anderson MJ, Diebelb CE, Blomb WM, Landers TJ (2005) Consistency and variation in kelp holdfast assemblages: Spatial patterns of biodiversity for the major phyla at different taxonomic resolutions. J Exp Mar Biol Ecol 320:35-56

Armitage CS, Sjøtun K (2016) Epiphytic macroalgae mediate the impact of a non-native alga on associated fauna. Hydrobiologia 776(1):35-49

Arroyo NL, Maldonado M, Perez-Portela R, Benito J (2004) Distribution patterns of meiofauna associated with a sublittoral Laminaria bed in the Cantabrian Sea (north-eastern Atlantic). Mar Biol 144:231-242

Atrill MJ, Bilton DT, Rowden AA, Rundle SD, Thomas RM (1996) An estuarine biodiversity hot-spot. J Mar Biol Ass UK 76:161-175

Barnes DKA, Kuklinski P (2003) High polar spatial competition: extreme hierarchies at extreme latitude. Mar Ecol Prog Ser 259:17-28

Berge J, Daase M, Renaud PE, Ambrose WG, Jr, Darnis G, Last KS, Leu E, Cohen JH, Johnsen G, Moline MA, Cottier F, Varpe $\varnothing$, Shunatova N, Balazy P, Morata N, Massabuau J-C, Falk-Petersen S, Kosobokova K, Hoppe CJM, Weslawski JM, Kuklinski P, Legezynska J, Nikishina D, Cusa M, Kedra M, WlodarskaKowalczuk M, Vogedes D, Camus L, Tran D, Michaud E, Gabrielsen TM, Granovitch A, Gonchar A, Krapp R, Callesen TA (2015) Unexpected Levels of Biological Activity during the Polar Night Offer New Perspectives on a Warming Arctic. Current Biol 25:1-7 
Berrill NJ (1930) Studies in tunicate development. Part I. General physiology of development of simple ascidians. Phil Trans Royal Soc Lond Ser B 218:37-78

Blight AJ, Thompson RC (2008) Epibiont species richness varies between holdfasts of a northern and a southerly distributed kelp species. J Mar Biol Assoc UK 88:469-475

Borum J, Pedersen MF, Krause-Jensen D, Christensen PB, Nielsen K (2002) Biomass, photosynthesis and growth of Laminaria saccharina in a high-arctic fjord, NE Greenland. Mar Biol 141:11-19

Carlsen BP, Johnsen G, Berge J, Kuklinski P (2007) Biodiversity patterns of macro-epifauna on diVerent lamina parts of Laminaria digitata and Saccharina latissima collected during spring and summer 2004 in Kongsfjorden, Svalbard. Polar Biol 30:939-943

Christie H, Jørgensen NM, Norderhaug KM, Waage-Nielsen E (2003) Species distribution and habitat exploitation of fauna associated with kelp (Laminaria hyperborea) along the Norwegian coast J Mar Biol Ass UK 83(4181):1-13

Christie H, Norderhaug KM, Fredriksen S (2009) Macrophytes as habitat for fauna. Mar Ecol Progr Ser 396:221233

Cottier FR, Tverberg V, Inall M.E, Svendsen H, Nilsen F, Griffiths C (2005) Water mass modification in an Arctic fjord through cross-shelf exchange: the seasonal hydrography of Kongsfjord, Svalbard. J. Geophys. Res Oceans 110: c12005

Dean RL, Connell JH (1987) Marine invertebrates in an algal succession III. Mechanisms linking habitat complexity with diversity. J Exp Mar Biol Ecol 109:249-273.

Denisenko NV (1983) On the method of assessing biomass of bryozoans. Zoologicheskii zhurnal (Russian journal of zoology) 62(11): 1729-1731 (in Russian)

Duggins DO, Eckman JE, Sewell AT (1990) Ecology of understory kelp environments. II. Effects of kelps on recruitment of benthic invertebrates. J Exp Mar Biol Ecol 143, 27-45

Edwards A (1980) Ecological studies of the kelp, Laminaria hyperborea, and its associated fauna in South-West Ireland. Ophelia 19(1):47-60

Eleftheriou A (2013) Methods for the study of marine benthos. Wiley-Blackwell

Ereskovsky A (2010) The comparative embryology of sponges. Springer Dordrecht Heidelberg London New York

Gee JM (1963) Pelagic life of Spirorbis larvae. Nature 198:1109-1110

Gee JM, Warwick RM (1994) Metazoan community structure in relation to the fractal dimensions of marine macroalgae. Mar Ecol Progr Ser 103:141-150.

Gerrodette T (1981) Dispersal of the solitary coral Balanophyllia elegans by demersal planular larvae. Ecology 62(3):611-619

Gomez I, Wulff A, Roleda MY, Huovinen P, Karsten U, Quartino ML, Dunton K, Wiencke C (2009) Light and temperature demands of marine benthic microalgae and seaweeds in polar regions. Botanica Marina 52:593608

Grenvald JC, Callesen TA, Daase M, Hobbs L, Darnis G, Renaud PE, Cottier F, Nielsen TG, Berge J (2016) Plankton community composition and vertical migration during polar night in Kongsfjorden. Polar Biol DOI $10.1007 / \mathrm{s} 00300-016-2015-\mathrm{x}$

Grzelak K, Kuklinski P (2010) Benthic assemblages associated with rocks in a brackish environment of the southern Baltic Sea. J Mar Biol Ass UK 90(1):115-124

Hellio C, Berge JP, Beaupoil C, Le Gal Y, Bourgougnon N (2002) Screening of marine algal extracts for antisettlement activities against microalgae and macroalgae. Biofouling 18:205-215.

Hellio C, Bremer G, Pons AM, Le Gal Y, Bourgougnon N (2000) Inhibition of the development of microorganisms (bacteria and fungi) by extracts of marine algae from Brittany, France. Appl Microbiol Biotechnol 54:543549.

Hornsey IS, Hide D (1976) The production of antimicrobial compounds by British marine algae III. Distribution of antimicrobial activity within the algal thallus, Brit Phycol Journ 11(2):175-181

Jones CG, Lawton JH, Shachak M (1994) Organisms as ecosystem engineers. Oikos 69:373-386

Jost L (2006) Entropy and diversity. Oikos 113(2):363-375

Kain JM (1963) Aspects of the biology of Laminaria hyperborean II. Age, weight and length. J Mar Biol Ass UK 43:129-151.

Kain JM (1971) Synopsis of the biological data on Laminaria hyperborea. F.A.O. Fish. Synopsis 87:1-74

Kelaher BP, Castilla JC (2005) Habitat characteristics influence macrofaunal communities in coralline turf more than mesoscale upwelling on the coast of Northern Chile. Estuarine, Coastal and Shelf Science 63: 155-165.

Knight-Jones EW (1951) Gregariousness and some other aspects of the setting behaviour of Spirorbis. J Mar Biol Assoc UK 30:201-222

Knight-Jones EW (1953) Decreased discrimination during setting after prolonged planktonic life in larvae of Spirorbis borealis (Serpulidae). J Mar Biol Assoc UK 32:337-345

Knowles LL, Bell S (1998) The influence of habitat structure in faunal-habitat associations in a Tampa Bay seagrass system, Florida. Bull Mar Sci, 62:781-794

Kovalenko KE, Thomaz SM, Warfe DM (2012) Habitat complexity: approaches and future directions. Hydrobiologia 685:1-17 
Krause-Jensen D, Marba N, Olesen B et al. (2012) Seasonal sea ice cover as principal driver of spatial and temporal variation in depth extension and annual production of kelp in Greenland. Global Ch Biol 18:2981-2994.

Kuklinski P (2009) Ecology of stone-encrusting organisms in the Greenland Sea-a review. Polar Res 28:222-237

Kuklinski P, Barnes DKA (2005) Microhabitat diversity of Svalbard Bryozoa. J Nat Hist 39(7): 539-554

Kuklinski P, Gulliksen B, Lønne OJ, Weslawski JM (2006) Substratum as a structuring influence on assemblages of Arctic bryozoans. Polar Biol 29:652-661

Kuklinski P, Berge J, McFadden L, Dmoch K, Zajaczkowski M, Nygård H, Piwosz K, Tatarek A (2013) Seasonality of occurrence and recruitment of Arctic marine benthic invertebrate larvae in relation to environmental variables. Polar Biol 36:549-560

Kupriyanova EK, Nishi E, Ten Hove HA, Rzhavsky AV (2001) Life-history pattern in serpulimorph polychaetes: ecological and evolutionary perspectives. Oceanogr an Mar Biol Ann Rev 39:1-101

Leclerc J-C, Riera P, Laurans M, Leroux C, Lévêque L, Davoult D (2015) Community, trophic structure and functioning in two contrasting Laminaria hyperborea forests. Estuarine, Coastal and Shelf Science 152:11-22

Lippert H, Iken K, Rachor E, Wiencke C (2001) Macrofauna associated with macroalgae in Kongsfjord (Spitsbergen) Polar Biol 24:512-522

Loke LHL, Todd PA (2016) Structural complexity and component type increase intertidal biodiversity independently of area. Ecology 97:383-393

Lund S (1959) The marine algae of East Greenland. I. Taxonomical part. Meddelelser om Grønland 156 (1):1-244

Lüning K.(1979) Growth strategies of three Laminaria species (Phaeophyceae) inhabiting diferent depth zones in the sublittoral region of Helgoland (North Sea). Mar Ecol Progr Ser 1:195-201

Lüning K (1990) Seaweeds: Their environment, biogeography and ecophysiology. Wiley, New York, p 527

Lüning K (1993) Environmental and internal control of seasonal growth in seaweeds. Hydrobiologia 260/261:1-14.

Makarov VN, Schoschina EV (1996) Dynamics and seasonal growth strategies of the brown alga Laminaria saccharina in the Barents Sea. Biologiya Morya (Vladivostok) 22(4):238-248 (in Russian).

Matias MG, Underwood AJ, Hochuli DF, Coleman RA (2010) Independent effects of patch size and structural complexity on diversity of benthic macroinvertebrates. Ecology 91(7):1908-1915

McCoy ED, Bell SS (1991) Habitat structure: the evolution and diversification of a complex topic. In: Bell, SS, McCoy ED, Mushinsky HR (eds) Habitat structure: the physical arrangement of objects in space. Chapman and Hall, London: 3-27

Meyer K, Sweetman A, Kuklinski P, Leopold P, Vogedes D, Berge J, Griffiths C, Young C, Renaud P (2017) Recruitment of benthic invertebrates in high Arctic fjords: relation to temperature, depth and season. Limnoly Oceanogr 62: 2732-2744 doi: 10.1002/lno.10602

Migotto AE (1998) The life cycle of Sertularia marginata Kirchenpauer, 1864 (Cnidaria: Hydrozoa): a medusoidproducing sertulariid. J Nat Hist 32:1-12

Miguel G, Matias MG, Underwood AJ, Hochuli DF, Coleman RA (2010) Independent effects of patch size and structural complexity on diversity of benthic macroinvertebrates. Ecology 91:1908-1915

Mileikovsky SA (1971) Types of larval development in marine bottom invertebrates, their distribution and ecological significance: a re-evaluation. Mar Biol 10:193-213

Norderhaug KM, Christie H, Fredriksen S (2007) Is habitat size an important factor for faunal abundances on kelp (Laminaria hyperborea)? J Sea Res 58:120-124

Norton TA (1971) An ecological study of the fauna inhabiting the subhttoral marine alga Saccorhiza polyschides (Lightf.) Batt. Hydrobiologia 37:215-231

Orlov D (1996) Observations on the settling behaviour of planulae of Clava multicornis Forskål (Hydroidea, Athecata). Sci Mar 60(1):121-128

Orlov DV (1997) The role of larval settling behaviour in determination of the specific habitat of the hydrozoan Dynamena pumila (L.) larval settlement in Dynamena pumila (L.). J Exp Mar Biol Ecol 208(1-2):73-85

Osman R W (1977) The establishment and development of a marine epifaunal community. Ecol Monogr 47:37-63

Parker JD, Emmett DJ, Orth RJ (2001) Plant species diversity and composition: experimental effects on marine epifauna assemblages. Mar Ecol Progr Ser 224:55-67.

Pearse JS (1969) Slow developing demersal embryos and larvae of the Antarctic sea star Odontaster validus. Mar Biol 3:110-116

Piwosz K, Walkusz W, Hapter R, Wieczorek P, Hop H, Wiktor J (2009) Comparison of productivity and phytoplankton in a warm (Kongsfjorden) and a cold (Hornsund) Spitsbergen fjord in midsummer 2002. Polar Biol 32:549-559

Reed DC, Nelson JC, Harrer SL, Miller RJ (2016) Estimating biomass of benthic kelp forest invertebrates from body size and percent cover data. Mar Biol 163:101 doi 10.1007/s00227-016-2879-x

Reed G (1991) Bryozoa. In: Giese AC, Pearse JC, Pearse VB (eds.): Reproduction of marine invertebrates. Vol VI. Echinoderms and Lophophorates. Pacific Grove: Boxwood Press, pp 85-245

Rozycki O, Gruszczynski M (1986) Macrofauna associated with laminarians in the coastal waters of West Spitsbergen. Polish Polar Res 7(4):337-351

Ryland JS (1974) Behaviour, settlement and metamorphosis of bryozoan larvae: A review. Thalassia Jugosl. 10:239262. 
Ryland JS (1976) Physiology and ecology of marine bryozoans. In: Russel F S, Yonge M (eds.): Advances in Marine Biology. Vol. 14. London: Academic Press, pp 285-443

Schaffelke B, Lüning K (1994) A circannual rhythm controls seasonal growth in the kelps Laminaria hyperborea and $L$. digitata from Helgoland (North Sea). Eur. J. Phycol. 29:49-56.

Schultze K, Janke K, Krüß A, Weidemann W (1990) The macrofauna and macroflora associated with Laminaria diffitata and L. hyperborea at the island of Helgoland (German Bight, North Sea) Helgol Meeresunters 44:3951 (1990)

Seed R, Harris S (1980) The epifauna of the fronds of Laminaria digitata Lamour in Strangford Lough, Northern Ireland. Proc R Ir Acad 80:91-106

Seed R, O'Connor RJ (1981) Community organization in marine algal epifauna. Annual Review of Ecology and Systematics 12:49-74

Sheppard CRC, Bellamy DJ, Sheppard ALS (1977) The fauna associated with Laminaria ochroleuca Pyl. In the Straits of Messina. Memorie di Biologia Marina edi Ocenografia 7:1-9

Shimeta J, Jumars PA (1991) Physical mechanisms and rates of particle capture by suspension feeders. Oceanogr Mar Biol Annu Rev 29:191-257

Smith SDA (1996) The macrofaunal community of Ecklonia radiata holdfasts: Variation associated with sediment regime, sponge cover and depth. Aust J Ecol 21(2):144-153

Smith SDA, Simpson RD, Cairns SC (1996) The macrofaunal community of Ecklonia radiata holdfasts: description of the faunal assemblage and variation associated with differences in holdfast volume. Aust J Ecol 21(1):8195.

Sommer C (1992) Larval biology and dispersal of Eudendrium racemosum (Hydrozoa, Eudendriidae). In: Bouillon J, Boero F, Cicogna F, Gili JM, Hughes RG (eds) Aspects of hydrozoan biology. Sci Mar 56:205-211

Sousa WP (1979) Disturbance in marine intertidal boulder fields: the nonequilibrium maintenance of species diversity. Ecology 60:1225-1239

Spurkland T, Iken K (2011) Kelp bed dynamics in estuarine environments in subarctic Alaska. Journal of Coastal Research 27 (6A):133-143

St. Pierre JI, Kovalenko KE (2014) Effect of habitat complexity attributes on species richness. Ecosphere 5(2):22.

Steneck RS, Graham MH, Bourque BJ, Corbett D, Erlandson JM, Estes JA, Tegner MJ (2002) Kelp forest ecosystems: biodiversity, stability, resilience and future. Environ Conserv 29:436-459

Stübner EI, Søreide JE, Reigstad M, Marquardt M, Blachowiak-Samolyk K (2016) Year-round meroplankton dynamics in high-Arctic Svalbard. J Plankton Res 38:522-536

Svane I, Young C M (1989) The ecology and behavior of ascidian larvae. Oceanogr Mar Biol Annu Rev 27:45-90

Svendsen H, Beszczynska-Møller A, Hagen JO, Lefauconnier B, Tverberg V, Gerland S, Ørbæk JB, Bischof K, Papucci C, Zajaczkowski M, Azzolini R, Bruland O, Wiencke C, Winther J-G, Dallmann W (2002) The physical environment of Kongsfjorden-Krossfjorden, an Arctic fjord system in Svalbard. Polar Res. 21:133166.

Villegas MJ, Laudien J, Sielfeld W, Arntz WE (2008) Macrocystis integrifolia and Lessonia trabeculata (Laminariales; Phaeophyceae) kelp habitat structures and associated macrobenthic community off northern Chile. Helgol Mar Res 62 (Suppl 1):33-43

Vogel S (1994) Life in moving fluids. Princeton University Press, Princeton, NJ

Walkusz W, Kwasniewski S, Falk-Petersen S, Hop H, Tverberg V, Wieczorek P, Weslawski JM (2009) Seasonal and spatial changes in the zooplankton community of Kongsfjorden, Svalbard. Polar Res 28:254-281

Ward MA, Thorpe JP (1989) Assessment of space utilization in a subtidal temperate bryozoan community. Mar Biol 103:215-224

Wiencke C, Amsler DC (2012) Seaweeds and their communities in polar regions. In: Wiencke C, Bischof K (eds.) Seaweed Biology. Vol. 219. Ecological Studies. Springer, Berlin Heidelberg pp 265-291

Wiencke C, Clayton MN, Gomez I, Iken K, Lüder UH, Amsler CD, Karsten U, Hanelt D, Bischof K, Dunton K (2007) Life strategy, ecophysiology and ecology of seaweeds in polar waters Rev Environ Sci Biotechnol 6:96-126

Wiencke C, Gomez I, Dunton K (2009) Phenology and seasonal biological performance of polar seaweeds. Botanica Marina 52:585-592

Williams GB (1965) Observations on the behaviour of the planulae larvae of Clava squamata. Helgoländer wissenschaftliche Meeresuntersuchungen 45:257-273.

Willis K, Cottier F, Kwasniewski S, Wold A, Falk-Petersen S (2006) The influence of advection on zooplankton community composition in an Arctic fjord (Kongsfjorden, Svalbard). Journal of Marine Systems 61:39-54.

Wilson MA (1987) Ecological dynamics on pebbles, cobbles, and boulders. Palaios 2:594-599

Withers RG, Farnham WF, Lewey S, Jephson NA, Haythorn JM, Gray PWG (1975) The Epibionts of Sargassum muticum in British Waters. Mar Biol 31:79-86

Wlodarska-Kowalczuk M, Kuklijski P, Ronowicz M,-Legeryjska J,-Gromisz S (2009) Assessing species richness of macrofauna associated with macroalgae in Arctic kelp forests (Hornsund, Svalbard) Polar Biol 32:897-905

Yakovis EL, Artemieva AV, Shunatova NN, Varfolomeeva MA (2008) Multiple foundation species shape benthic habitat islands. Oecologia 155:785-795 
814 Fig. 1 Portion of " $0+$ " year-zone of the blades of Saccharina latissima (percentage of total surface area of blade)

815 Error bars show standard error.

Fig. 2 Average and total species richness on different substrate types (all seasons together)

818 Error bars show standard error.

Fig. 3 Seasonal dynamic of species richness in zoo- and phytobenthos at $2 \mathrm{~m}$ depth

Fig. 4 Seasonal dynamic of total biomass of macrobenthic organisms at $2 \mathrm{~m}$ depth

Fig. 5 Biplot of substrates distribution in Principal Component Analysis (based on four-root transformed data on density of macrozoobenthos at $2 \mathrm{~m}$ depth)

Dotted lines correspond to loading vectors of species that significantly contributed to the first and second components.

Fig. 6 Seasonal dynamic of total biomass of dominant and leading species (left column - animals, right column algae) at $2 \mathrm{~m}$ depth

833

Fig. 7 Distribution of adults and juveniles of leading species on blades of Saccharina latissima Error bars show standard error. 